\title{
Bilateral Superior Cervical Ganglionectomy and Melatonin Levels in Rat Subarachnoid Hemorrhage Model: Simple Precautions May Preserve Melatonin Levels
}

\author{
Siçan Subaraknoid Kanama Modelinde Bilateral Superior Servikal Ganglionektomi ve Melatonin \\ Seviyeleri: Basit Önlemler Melatonin Düzeylerini Koruyabilir
}

\author{
Güven KILIÇ ${ }^{1}$ \\ (1) 0000-0001-5050-7908 \\ Murat KAYABAŞ ${ }^{2}$ \\ (D) 0000-0002-5768-2925 \\ Seçkin Emre CANCAN ${ }^{3}$ \\ (D) 0000-0002-3260-7419
}

\begin{abstract}
${ }^{1}$ Department of Neurosurgery, Düzce University Faculty of Medicine, Düzce, Turkey
\end{abstract}

${ }^{2}$ Department of Neurosurgery, Kafkas University Faculty of Medicine, Kars, Turkey State Hospital, Bolu, Turkey
${ }^{3}$ Neurosurgery Clinics, İzzet Baysal

\begin{abstract}
Aim: Subarachnoid hemorrhage (SAH) is a serious disease, and it is thought that melatonin may have positive effects after SAH. Bilateral resection or blockage of superior cervical ganglions has constant effects on melatonin levels. Animal models with bilateral superior cervical ganglionectomy (SCG) show the role of superior cervical ganglion on melatonin and give clues about simple precautions which may help to prevent unfavorable outcomes in SAH patients. The aim of this study is to examine how melatonin levels change in SAH and SCG models.

Material and Methods: Forty-two Sprague Dawley male rats weighing 200-250 g were used in the study and randomly divided into six groups. Arterial blood samples were collected 24 hours after the procedure in all groups. Serum melatonin levels of the groups were studied. Results: A significant difference in blood melatonin levels was observed between SAH and SCG groups, and against the control group. There was no significant difference between the melatonin levels in $\mathrm{SCG}$ group and $\mathrm{SAH}+\mathrm{SCG}$ group $(\mathrm{p}=0.983)$. The mean blood melatonin level of the SAH group was higher than the SCG $(p<0.001)$, SAH+SCG $(p<0.001)$ and control groups $(\mathrm{p}=0.001)$. The mean blood melatonin levels of SAH+SCG and SCG groups were lower than the mean blood melatonin levels of the other groups and also the $\mathrm{SAH}$ group $(\mathrm{p}<0.001)$. Conclusion: Bilateral SCG significantly inhibited the abrupt increase of serum melatonin levels after SAH model in rats. Future studies aiming to address melatonin's complex outcomes should take into account that minor exogenous factors may affect serum melatonin levels.

Keywords: Superior cervical ganglion; subarachnoid hemorrhage; melatonin.
\end{abstract}

\section{ÖZ}

Amaç: Subaraknoid kanama (subarachnoid hemorrhage, SAH) ciddi bir hastalıktır ve SAH sonrası melatoninin olumlu etkileri olabileceği düşünülmektedir. Superior servikal ganglionların bilateral rezeksiyonu veya blokajı melatonin seviyeleri üzerinde sabit etkilere sahiptir. Bilateral superior servikal ganglionektomili (superior cervical ganglionectomy, SCG) hayvan modelleri, superior servikal ganglionun melatonin üzerindeki rolünü göstermekte ve SAH hastalarında olumsuz sonuçların önlenmesine yardımcı olabilecek basit önlemler hakkında ipuçları vermektedir. Bu çalışmanın amacı SAH ve SCG modellerinde melatonin düzeylerinin nasıl değiştiğinin incelenmesidir.

Gereç ve Yöntemler: Çalışmada 200-250 g ağırlığında kırk iki adet Sprague Dawley erkek sıçan kullanıldı ve rastgele şekilde altı gruba ayrıldı. Tüm gruplarda işlemden 24 saat sonra arteriyel kan örnekleri alındı. Grupların serum melatonin düzeyleri çalışıldı.

Bulgular: SAH ve SCG grupları arasında ve kontrol grubuna karşı kan melatonin düzeylerinde anlamlı farklılık gözlendi. SCG grubu ve SAH+SCG grubu melatonin değerleri arasında anlamlı bir fark yoktu $(\mathrm{p}=0,983)$. SAH grubunun ortalama kan melatonin düzeyi, SCG $(\mathrm{p}<0,001), \mathrm{SAH}+\mathrm{SCG}(\mathrm{p}<0.001)$ ve kontrol $(\mathrm{p}=0.001)$ gruplarından daha yüksekti. SAH+SCG ve SCG gruplarının ortalama kan melatonin düzeyleri, diğer grupların ve ayrıca $\mathrm{SAH}$ grubunun da $(\mathrm{p}<0,001)$ ortalama kan melatonin düzeylerinden daha düşüktü.

Sonuç: Bilateral SCG, sıçanlarda SAH modelinden sonra serum melatonin düzeylerinin ani artışını önemli ölçüde inhibe etti. Melatoninin karmaşık sonuçlarını ele almayı amaçlayan gelecekteki çalışmalar, minör eksojen faktörlerin serum melatonin düzeylerini

Accepted / Kabul Tarihi : 08.12.2021 Available Online /

Çevrimiçi Yayın Tarihi : 15.12.2021 etkileyebileceğini hesaba katmalı ve göz önünde bulundurmalıdır.

Anahtar kelimeler: Superior servikal ganglion; subaraknoid kanama; melatonin. 


\section{INTRODUCTION}

Subarachnoid hemorrhage (SAH) is a serious disease that develops spontaneously or due to trauma, and it is thought that melatonin may have positive effects on SAH (1-3). Melatonin secretion in the pineal gland is regulated by light stimulation, and superior cervical ganglion has an important place in this regulation (4-6). Whether traumatic or spontaneous SAH can be defined as extravasation of blood into subarachnoid space of brain $(7,8)$. Trauma which is the leading cause of $\mathrm{SAH}$, is followed by other pathophysiological reasons in the list such as aneurysmatic SAH and peri-mesencephalic SAH; e.g. vascular malformation, intracranial dissection, sickle cell disease with intracerebral hemorrhage, pituitary apoplexy, cerebral amyloid angiopathy, central nervous system tumor, cocaine use, and cerebral venous thrombosis (9).

Although a remarkable decline in the incidence of aneurysmatic SAH worldwide is seen decade by decade it is not to lose its importance since almost $45 \%$ of cases end up with mortality in the first month after the incident and nearly $30 \%$ of the survivals will face off disabilities at some degree $(7,10)$. Various papers in the literature studied effects of melatonin in early and delayed ischemia and vasospasm after SAH (11-15).

Melatonin as an endogenous antioxidant, seems to have an important role in maintaining favorable outcomes in $\mathrm{SAH}$ survivors $(12,16,17)$. Therefore, safe methods to achieve the goal to increase this endogenous melatonin should be put in charge.

Supplying sympathetic innervation to head and neck, superior cervical ganglion plays an important role in regulating basilar and middle cerebral arteries $(18,19)$. Melatonin which is a derivative of serotonin, is synthesized in pinealocytes and this procedure is regulated by ambient light through a neural pathway from the retina, ending in sympathetic neurons of the superior cervical ganglion $(6,20)$. Bilateral resection or blockage of superior cervical ganglions has constant effects on melatonin levels (21-24). Thus, blockage of superior cervical ganglion leaves ajar a door to pass into the world of CVS by its roles in melatonin synthesis and sympathetic nervous system.

Horner's Syndrome like outcomes of cervical hyperextension, due to stretching of the cervical sympathetic chain or ischemia, have been reported in the literature which may implicate that superior cervical ganglia can be affected by the position of the patient or pressure applied by ties used to stabilize the endotracheal intubation tubes in the intensive care units (25).

Melatonin has shown to have neuroprotective effects and reduce SAH induced oxidative stress $(16,26)$. So not only the effects of vasospasm also neuroprotection makes melatonin a remarkable molecule in management of SAH. Therefore, precautions to protect endogenous melatonin levels become important in daily practice regarding $\mathrm{SAH}$ patients.

Patient's head and neck position during and after the surgery, and the method to stabilize the intubation tube become very important in preserving melatonin levels induced after SAH. Performing bilateral superior cervical ganglionectomy (SCG) in animal models shows the role of superior cervical ganglion in biological mechanisms of melatonin and gives us clues about simple precautions which may help to prevent unfavorable outcomes in SAH patients.

The aim of this study is to examine how melatonin levels change in SAH and SCG models by comparing blood melatonin levels of control, sham, SAH and SCG groups.

\section{MATERIAL AND METHODS}

All procedures in this study were performed after the approval of the Animal Research and Ethics Committee of Kafkas University (date: 17/05/2018 and 25/10/2018, number: 2018/052 and 2018/081) and in accordance with the rules and procedures determined by the committee.

A total of 42 Sprague Dawley male rats weighing 200-250 g were used in the study. All animals were kept in the same physical environment, day and night, during the experiment and randomly divided into 6 groups. The average temperature of the room where the rats were kept was between $22-24{ }^{\circ} \mathrm{C}$ and with no existing windows. Free access to food and water (ad libitum) was provided under a 12-hour light/dark cycle (light off at 07:00 AM and 7:00 PM). The rats were randomized into six groups with $\mathrm{n}=7$ in each group as follows: Group 1: Control group, Group 2: Sham group for subarachnoid hemorrhage (SAH Sham), Group 3: Sham group for superior cervical ganglionectomy (SCG Sham), Group 4: SAH group, Group 5: SCG group, and Group 6: SAH+SCG group.

\section{Anesthesia}

Ketamine $35 \mathrm{mg} / \mathrm{kg}$ (Ketolar Panke Davis-Apothecary, Turkey) and xylazine 5-10 $\mathrm{mg} / \mathrm{kg}$ (Rompun-Bayer, Turkey) mixture was given by intraperitoneal injection. Anesthesia was determined as the rats to be unresponsive to pain and continue spontaneous respiration during the experiment; additional doses were given if necessary.

\section{Superior Cervical Ganglionectomy (SCG)}

After the rats were fixed to the dissection table under general anesthesia, the neck area was shaved and disinfected properly. Approximately 3-3.5 cm of vertical incision was performed from the intermandibular area to the presternal area, after which the skin was pulled with the retractors and deepened through the right and left mandibular salivary glands. Subsequently, the skin was pulled up and out, the layers of thin tissue between the mandibular glands and the muscles here were cut off, and the deep cervical fascia was dissected with blunt and sharp dissections. Superior cervical ganglion was identified at carotid bifurcation. To prevent external carotid artery trauma, the external carotid artery was removed using the surrounding connective tissue and then the superior cervical ganglion was visualized, subsequently superior cervical ganglion was removed by small traction maneuvers. The same procedure was repeated for the contralateral side and at the end of the procedure the skin was closed with $4 / 0$ prolene sutures.

\section{Subarachnoid Hemorrhage (SAH)}

After general anesthesia, rats were shaved between inion and atlas. After cleaning the area with povidone-iodine solution, approximately $2 \mathrm{~cm}$ long skin incision between inion and atlas was made. The occipital muscles were dissected with blunt dissection from the bone, after which posterior cervical muscle was dissected and atlantooccipital membrane was revealed. $0.1 \mathrm{ml}$ non-heparinized blood 
was collected from the tail artery and injected into cisterna magna within 30s following the discharge of an equal amount of cerebrospinal fluid (CSF).

To prevent blood from leaking back, the insulin shot was briefly held at the point where it entered the membrane. After this procedure, rats were kept in the Trendelenburg position for 15-20 minutes, to achieve the blood to reach into the prepontine cistern.

\section{Measurement of Serum Melatonin Level}

Arterial blood samples up to $0.2 \mathrm{ml}$ were collected from the tail 24 hours after the procedure (09:00 in the morning) in all groups and rats were sacrificed with deep anesthesia. After clotting in the blood samples, they were centrifuged for 20 minutes at $3000 \mathrm{rpm}$ and the supernatant (serum) was aliquoted and stored at $-80{ }^{\circ} \mathrm{C}$ until the measurement. Commercial ELISA kit (MyBioSource, Melatonin (MLT) ELISA Kit, USA, Catalog No: MBS020998) was used for serum melatonin measurements.

\section{Statistical Analysis}

Obtained data were analyzed with IBM SPSS Statistics 22 program. Shapiro-Wilk test was performed to evaluate normal distribution of blood melatonin levels, and skewness and kurtosis values were also studied. The Levene test was used to analyze homogeneity of variance. A one-way ANOVA test was performed to find the difference between groups in terms of blood melatonin levels. Post-hoc Tukey test was performed to determine significant differences between groups. Blood melatonin level for each group were presented with mean and standard deviation. A $p$ value of $<0.05$ was considered as statistically significant.

\section{RESULTS}

The comparison of blood melatonin levels between groups were presented in Table 1. There was a significant difference in terms of melatonin levels between the groups $\left(\mathrm{F}_{(5,36)}=18.779, \eta 2=0.723, \mathrm{p}<0.001\right)$. Post-hoc Tukey test was used to find out the significance regarding the differences in blood melatonin levels between the groups. A significant difference in terms of the blood melatonin levels was observed between SAH and SCG groups, and also against the control group. According to the post hoc test result, there was no significant difference between the mean melatonin levels in SCG group and $\mathrm{SAH}+\mathrm{SCG}$ group (101.02 \pm 18.22 vs. $111.28 \pm 17.04$, respectively, $\mathrm{p}=0.983$ ).

When control and sham groups compared, mean blood melatonin levels were as follows and no significant difference was observed between control, SAH sham and SCG sham groups; $160.72 \pm 25.63$ in control group, $167.04 \pm 28.47$ in SAH sham (occipital incision) group, and $170.85 \pm 34.07$ in SCG sham (cervical incision) group $(p=0.998$ for control vs. SAH sham, $p=0.984$ for control vs. SCG sham, and $\mathrm{p}=0.999$ for $\mathrm{SAH}$ sham vs. SCG sham).
The mean blood melatonin level of the $\mathrm{SAH}$ group $(228.98 \pm 39.23)$ was higher than the mean blood melatonin level of control group $(\mathrm{p}=0.001)$, SAH sham group $(p=0.003)$, SCG sham group $(p=0.006)$, SCG group $(\mathrm{p}<0.001)$ and $\mathrm{SAH}+\mathrm{SCG}$ group $(\mathrm{p}<0.001)$, and all these differences were found as statistically significant.

The mean blood melatonin levels of SAH+SCG and SCG groups were lower than the mean blood melatonin levels of the other groups $(p=0.026$ for $\mathrm{SAH}+\mathrm{SCG}$ vs. control, $\mathrm{p}=0.009$ for $\mathrm{SAH}+\mathrm{SCG}$ vs. $\mathrm{SAH}$ sham, $\mathrm{p}=0.004$ for $\mathrm{SAH}+\mathrm{SCG}$ vs. SCG sham, $\mathrm{p}=0.004$ for SCG vs. control, $p=0.001$ for $S C G$ vs. $S A H$ sham, $p=0.001$ for SCG vs. SCG sham); and all these differences were significant (Figure 1, Table 1).

These results indicated that blood melatonin levels were increased significantly after $\mathrm{SAH}$, decreased in rats which undergone SCG, and blood melatonin levels did not increase after SAH in rats with SCG.

\section{DISCUSSION}

With the obtained results from this study, we observed that bilateral SCG reduces melatonin production. This blockage eventually will decrease the effects of melatonin on vasospasm and further neuroprotective effects of melatonin should not be expected to occur $(12,13,16,26-28)$.

Sole increase in melatonin levels seen in the $\mathrm{SAH}$ group shows the successful modelling of SAH and also is parallel to the findings in the literature; prominent increase in melatonin levels is in correlation with the severity of SAH as a natural response to the event (29). Thus, inhibiting the increase in melatonin levels by bilateral SCG, prohibits this natural response causing a significant lack for melatonin's protective effects after SAH.

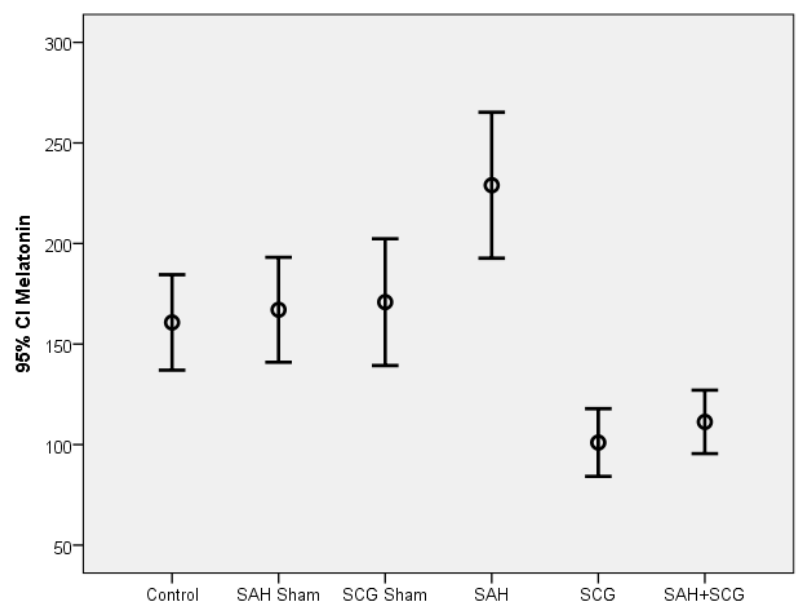

SAH: subarachnoid hemorrhage, SCG: superior cervical ganglionectomy Figure 1. Mean blood melatonin levels in groups

Table 1. Comparison of blood melatonin levels in groups

\begin{tabular}{|c|c|c|c|c|c|c|c|}
\hline & Control & SAH Sham & SCG Sham & SAH & SCG & $\mathrm{SAH}+\mathrm{SCG}$ & $\mathbf{p}$ \\
\hline Melatonin & $160.72 \pm 25.63$ & $167.04 \pm 28.47$ & $170.85 \pm 34.07$ & $228.98 \pm 39.23$ & $101.02 \pm 18.22$ & $111.28 \pm 17.04$ & $<0.001$ \\
\hline
\end{tabular}


Previously mentioned cases in the literature, such as Horner's Syndrome like outcomes of cervical hyperextension, due to stretching of the cervical sympathetic chain or ischemia; highlights the importance of intraoperative positioning and also postoperative patient care in intensive care units (25). Possible compression or damage to the superior cervical ganglion may end up with decreased levels of melatonin. Interventions like central venous catheterization (CVC) into internal jugular vein (IJV) may also result in damage to the superior cervical ganglion (30).

As underlined by Aulinas A. (6) in 2019, other possible production sites of melatonin seem not to contribute much in secretion of the hormone after pinealectomy; in parallel to this statement we also report no significant change in rats which undergone bilateral SCG. Therefore, simple precautions during the treatment period of SAH patients may become more important to keep melatonin levels at a preserved level. The effect of light on melatonin secretion should be kept in mind, so the ambient luminescence in the intensive care units becomes an unnoticed additive factor in an avalanche covering the total war of saving neuroprotection after SAH. Even though debatable effects of exogenous factors can be questioned, choice of analgesic medication can also be a part of this struggle; for example, ibuprofen can reduce melatonin secretion. Inadequate sedation in patients may result in agitation of the intubated patient which leads intensive care unit (ICU) staff to be more rigid to keep safe the intubation tubes and to knot the stabilizers more tightly on the neck; at this point one should be more alert to keep superior cervical ganglia away from pressure.

Studies in the literature like Zhan et al. (29) have detailed inclusion and exclusion criteria regarding SAH patients and their melatonin levels. A significant correlation between high serum melatonin levels and poor outcome is concluded in this study, but it should not be ignored that severity of SAH itself can be in correlation to increased melatonin levels and poor outcomes; and also, perioperative interventions and ICU precautions can theoretically affect melatonin levels in this group of patients.

Not only in topic of SAH, also numerous papers in the literature studied spinal cord injury-melatonin correlation in animal models and human subjects (31-36). For the future designs of the studies both in animal models and humans, exogenous factors and superior cervical ganglia injuries should be considered in evaluating serum melatonin levels since bilateral SCG significantly reduces melatonin response of the body.

\section{CONCLUSION}

With this plain study design, we presented that bilateral SCG significantly inhibits the abrupt increase of serum melatonin levels after SAH model in rats. A second study is in our scope to evaluate pinealocytes' changes and responses to bilateral SCG. Further studies are needed to unveil the effects of melatonin after both spinal traumas and SAH. Also, future studies aiming to address melatonin's complex outcomes should take into account that minor exogenous factors may affect serum melatonin levels.
Ethics Committee Approval: The study was approved by the Animal Experiments Ethics Committee of Kafkas University (17.05.2018, 052; 25.10.2018, 081).

Conflict of Interest: None declared by the authors.

Financial Disclosure: None declared by the authors.

Acknowledgements: None declared by the authors.

Author Contributions: Idea/Concept: GK; Design: GK, MK; Data Collection/Processing: GK, MK; Analysis/Interpretation: MK; Literature Review: SEC; Drafting/Writing: SEC; Critical Review: GK, MK, SEC.

\section{REFERENCES}

1. Natuva SSK, Gandra S. Subarachnoid hemorrhage. In: Ranganathan LN, editor. Reviews in Neurology. New Delhi: Wolters Kluwer India; 2019. p.266-72.

2. Li S, Yang S, Sun B, Hang C. Melatonin attenuates early brain injury after subarachnoid hemorrhage by the JAK-STAT signaling pathway. Int J Clin Exp Pathol. 201912(3):909-15.

3. Gunata M, Parlakpinar H, Acet HA. Melatonin: A review of its potential functions and effects on neurological diseases. Rev Neurol (Paris). 2020;176(3):148-65.

4. Hardeland R, Pandi-Perumal S, Cardinali DP. Melatonin. Int J Biochem Cell Biol. 2006;38(3):313-6.

5. Samanta S. Physiological and pharmacological perspectives of melatonin. Arch Physiol Biochem. 2020; [Epub ahead of print]. doi: 10.1080/13813455.2020.1770799.

6. Aulinas A. Physiology of the pineal gland and melatonin. [Updated 2019 Dec 10]. In: Feingold KR, Anawalt B, Boyce A, Chrousos G, de Herder WW, Dhatariya K, et al, editors. Endotext [Internet]. South Dartmouth (MA): MDText.com, Inc.; 2000.

7. Abraham MK, Chang WW. Subarachnoid hemorrhage. Emerg Med Clin North Am. 2016;34(4):901-16.

8. Djelilovic-Vranic J, Basic-Kes V, Tiric-Campara M, Djozic E, Kulenovic J. Follow-up of vasospasm by Transcranial Doppler Sonography (TCD) in subarachnoid hemorrhage (SAH). Acta Inform Med. 2017;25(1):14-8.

9. Long B, Koyfman A, Runyon MS. Subarachnoid hemorrhage: updates in diagnosis and management. Emerg Med Clin North Am. 2017;35(4):803-24.

10. Etminan N, Chang HS, Hackenberg K, de Rooij NK, Vergouwen MDI, Rinkel GJE, et al. Worldwide incidence of aneurysmal subarachnoid hemorrhage according to region, time period, blood pressure, and smoking prevalence in the population: a systematic review and meta-analysis. JAMA Neurol. 2019;76(5):588-97.

11. Dagistan Y, Kilinc E, Balci CN. Cervical sympathectomy modulates the neurogenic inflammatory neuropeptides following experimental subarachnoid hemorrhage in rats. Brain Res. 2019; $1722: 146366$.

12. Chun-jing H, Shan O, Guo-dong L, Hao-xiong N, Yiran L, Ya-ping F. Effect of cervical sympathetic block on cerebral vasospasm after subarachnoid hemorrhage in rabbits. Acta Cir Bras. 2013;28(2):89-93. 
13. Cao S, Shrestha S, Li J, Yu X, Chen J, Yan F, et al. Melatonin-mediated mitophagy protects against early brain injury after subarachnoid hemorrhage through inhibition of NLRP3 inflammasome activation. Sci Rep. 2017;7(1):2417.

14. Aydin MV, Caner H, Sen O, Ozen O, Atalay B, Cekinmez M, et al. Effect of melatonin on cerebral vasospasm following experimental subarachnoid hemorrhage. Neurol Res. 2005;27(1):77-82.

15. Aladag MA, Turkoz Y, Parlakpinar H, Ozen H, Egri M, Unal SC. Melatonin ameliorates cerebral vasospasm after experimental subarachnoidal haemorrhage correcting imbalance of nitric oxide levels in rats. Neurochem Res. 2009;34(11):1935-44.

16. Ersahin M, Toklu HZ, Cetinel S, Yüksel M, Yeğen BC, Sener G. Melatonin reduces experimental subarachnoid hemorrhage-induced oxidative brain damage and neurological symptoms. J Pineal Res. 2009;46(3):324-32.

17. Osier N, McGreevy E, Pham L, Puccio A, Ren D, Conley YP, et al. Melatonin as a therapy for traumatic brain injury: a review of published evidence. Int J Mol Sci. 2018;19(5):1539.

18. Nie Y, Song R, Chen W, Qin Z, Zhang J, Tang J. Effects of stellate ganglion block on cerebrovascular vasodilation in elderly patients and patients with subarachnoid haemorrhage. $\mathrm{Br} \mathrm{J}$ Anaesth. 2016;117(1):131-2.

19. Hu N, Wu Y, Chen BZ, Han JF, Zhou MT. Protective effect of stellate ganglion block on delayed cerebral vasospasm in an experimental rat model of subarachnoid hemorrhage. Brain Res. 2014;1585:63-71.

20. López-Muñoz F, Srinivasan V, de Berardis D, Álamo C, Kato TA. Melatonin, neuroprotective agents and antidepressant therapy: New Delhi: Springer, 2016.

21. Cardinali DP, Faigón MR, Scacchi P, Moguilevsky J. Failure of melatonin to increase serum prolactin levels in ovariectomized rats subjected to superior cervical ganglionectomy or pinealectomy. J Endocrinol. 1979;82(2):315-9.

22. Cardinali DP. Changes in hypothalamic neurotransmitter uptake following pinealectomy, superior cervical ganglionectomy or melatonin administration to rats. Neuroendocrinology. 1975;19(1):91-5.

23. Cardinali DP, Cutrera RA, Bonacho MG, Esquifino AI. Effect of pinealectomy, superior cervical ganglionectomy, or melatonin treatment on 24-hour rhythms in ornithine decarboxylase and tyrosine hydroxylase activities of rat spleen. J Pineal Res. 1997;22(4):210-20.

24. Saboureau M, Vivien-Roels B, Pevet P. Pineal melatonin concentrations during day and night in the adult hedgehog: effect of a light pulse at night and superior cervical ganglionectomy. J Pineal Res. 1991;11(2):92-8.

25. Atkinson D, McCluskey A, Richardson AM. Horner's syndrome after general anaesthesia. Anaesthesia. 2005;60(1):99-100.

26. Tan HY, Ng KY, Koh RY, Chye SM. Pharmacological effects of melatonin as neuroprotectant in rodent model: a review on the current biological evidence. Cell Mol Neurobiol. 2020;40(1):25-51.

27. Guo ZN, Jin H, Sun H, Zhao Y, Liu J, Ma H, et al. Antioxidant melatonin: potential functions in improving cerebral autoregulation after subarachnoid hemorrhage. Front Physiol. 2018;9:1146.

28. Fang Q, Chen G, Zhu W, Dong W, Wang Z. Influence of melatonin on cerebrovascular proinflammatory mediators expression and oxidative stress following subarachnoid hemorrhage in rabbits. Mediators Inflamm. 2009;2009:426346.

29. Zhan CP, Zhuge CJ, Yan XJ, Dai WM, Yu GF. Measuring serum melatonin concentrations to predict clinical outcome after aneurysmal subarachnoid hemorrhage. Clin Chim Acta. 2021;513:1-5.

30. Butty Z, Gopwani J, Mehta S, Margolin E. Horner's syndrome in patients admitted to the intensive care unit that have undergone central venous catheterization: a prospective study. Eye (Lond). 2016;30(1):31-3.

31. Gezici AR, Karakaş A, Ergün R, Gündüz B. Rhythms of serum melatonin in rats with acute spinal cord injury at the cervical and thoracic regions. Spinal Cord. 2010;48(1):10-4.

32. Kaptanoglu E, Tuncel M, Palaoglu S, Konan A, Demirpençe E, Kilinç K. Comparison of the effects of melatonin and methylprednisolone in experimental spinal cord injury. J Neurosurg. 2000;93(Suppl 1):7784.

33. Klein D, Smoot R, Weller JL, Higa S, Markey SP, Creed GJ, et al. Lesions of the paraventricular nucleus area of the hypothalamus disrupt the suprachiasmatic leads to spinal cord circuit in the melatonin rhythm generating system. Brain Res Bull. 1983;10(5):647-52.

34. Scheer FA, Zeitzer JM, Ayas NT, Brown R, Czeisler CA, Shea SA. Reduced sleep efficiency in cervical spinal cord injury; association with abolished night time melatonin secretion. Spinal Cord. 2006;44(2):7881.

35. Zeitzer JM, Ayas NT, Shea SA, Brown R, Czeisler CA. Absence of detectable melatonin and preservation of cortisol and thyrotropin rhythms in tetraplegia. J Clin Endocrinol Metab. 2000;85(6):2189-96.

36. Fatima G, Sharma VP, Verma NS. Circadian variations in melatonin and cortisol in patients with cervical spinal cord injury. Spinal Cord. 2016;54(5):364-7. 